\title{
THE RELATIONSHIP BETWEEN OPACITY FACTOR AND M PROTEIN IN STREPTOCOCCUS PYOGENES
}

\author{
Gillian Hallas and Jean P. Widdowson
}

Division of Hospital Infection, Central Public Health Laboratory, Colindale Avenue, London NW9 5 HT

\begin{abstract}
Summary. Lancefield acid extracts of Streptococcus pyogenes, type 22 (T12, M22, OF positive) gave good yields of M protein and little opacity factor (OF), but sodium dodecyl sulphate (SDS) extracts contained high titres of OF $(>20000)$ and little M protein. Acid-extracted OF could be separated from $M$ protein by Sepharose 4B chromatography, but some of the OF-positive fractions that did not precipitate with the absorbed homologous anti-M rabbit serum, were able to neutralise opsonic antibodies present in human serum. The isoelectric-focusing profiles of the two antigens showed partial similarity.

Some strains of the OF-positive serotypes, e.g., M-types 22 and 49, lost both $\mathrm{M}$ antigen and OF activity on serial transfer in Todd-Hewitt broth, but this was not seen in a representative of M-type 60 , and no $M$-negative OF-negative variants could be detected after six subcultures. Among the OF-negative serotypes some, e.g., M-types 5 and 6, were completely stable, whereas others, e.g., M-types 12,55 and 57 , lost their $M$ antigens after serial subculture. One explanation is that the genes that code for $M$ antigen are plasmid borne in some serotypes and, moreover, are carried on the same plasmid as the gene for OF in some OF-positive serotypes. However, analysis of cell lysates by agarose-gel electrophoresis failed to demonstrate the presence of plasmid DNA in any of the strains tested.
\end{abstract}

\section{INTRODUCTION}

The production of opacity in horse serum (opacity factor; OF) is a constant characteristic of all strains of certain M types of Streptococcus pyogenes and is consistently absent from members of other $M$ types (Gooder, 1961; Top and Wannamaker, 1968). The antigenic specificity of OF parallels that of $M$ antigen (Widdowson, Maxted and Grant, 1970) and a typing scheme based on the neutralisation of the opacity reaction by specific antisera is well established (Maxted et al., 1973). The parallel specificity of the two antigens suggests that they may be closely related, but there have been conflicting reports on the possible nature of this relationship. In this study we have investigated the suggestion that the two antigens are physicochemically linked and represent different biological activities on the same protein molecule (Widdowson et al., 1971a). We have also examined another 
possibility, suggested by the work of Cleary, Johnson and Wannamaker (1975), that OF and $\mathrm{M}$ protein are coded for by different genes on the same plasmid.

\section{MATERIALS AND METHODS}

Strains. Streptococcus pyogenes strain R68/3116 (serotype T12, M22, OF positive) was used to investigate the physico-chemical nature of the relationship between $M$ protein and OF. The OF-positive strains used in serial subculture experiments were numbered: R68/3116 (M22), DS/C2741/1 (M49) and R69/2702 (M60). The OF-negative strains used were numbered: T5/B/PS (M5), NCTC8302 (M6), 1130 (M12), NCTC10873 (M55) and NCTC10875 (M57). Strain 105/35/72 (AC-1) serotype T12, M22, OF positive (erythromycin and lincomycin resistant) and an antibiotic-sensitive derivative (AC-2) were obtained from $\mathrm{Dr}$ D. B. Clewell, University of Michigan.

Growth of streptococci. Strain R68/3116 was grown overnight at $37^{\circ} \mathrm{C}$ in Todd-Hewitt Broth (Difco Ltd, Chertsey, Surrey) supplemented with Neopeptone (Difco; $2 \% \mathrm{w} / \mathrm{v}$ ). The cells were sedimented by centrifugation at $1500 \mathrm{~g}$ for $20 \mathrm{~min}$ and washed three times with physiological saline.

Antisera. Rabbit M-typing sera used for the detection of $\mathrm{M}$ proteins by double-gel diffusion, were absorbed sera prepared by the Streptococcus Reference Unit, Division of Hospital Infection, Colindale by the method of Williams and Maxted (1955).

The antiserum used in the complement-fixation test for the detection of M-type 22 antigen was prepared in a guinea pig by four to six weekly injections $(0.5 \mathrm{ml}$ intraperitoneally and $0.25 \mathrm{ml}$ subcutaneously) of a saline-washed, heat-killed vaccine of M-type 22 strain R68/3116. This serum, which exhibited no anti-OF activity, was screened in complement-fixation tests against the Lancefield extracts of type 22 and at least 20 heterologous $M$ types. At a dilution of 200 it reacted specifically with the type 22 extract.

The antiserum for the detection of the M-associated protein (MAP) antigen (MAP II) of OF-positive serotypes (Widdowson, Maxted and Pinney, 1976; Widdowson, 1980) was prepared in guinea pigs by the same method as described above for the anti-M serum, except that an $\mathrm{M}$-type 62 strain (NCTC10880) was used as the vaccine strain. The serum, at a dilution of 200 , fixed complement with the Lancefield extracts or MAP antigens of OF-positive but not of OF-negative serotypes. In some experiments, a human serum (MS) at a dilution of 15 , was also used for the detection of MAP II.

A suitable human serum was used as a source of antibody to the MAP antigen (MAP I) of OF-negative serotypes (Widdowson et al., 1976). At a dilution of 20 the serum fixed complement with Lancefield extracts of OF-negative serotypes only.

Extraction of $O F$ and $M$ protein. Washed cells were treated for $10 \mathrm{~min}$ at $10^{\circ} \mathrm{C}$ or $56^{\circ} \mathrm{C}$ with either $0.2 \mathrm{~N} \mathrm{HCl}$ or $0.05 \mathrm{~N} \mathrm{NaOH}$ (Hallas and Widdowson, 1982). Extraction with the detergents sodium dodecyl sulphate (SDS) $1 \%(\mathrm{w} / \mathrm{v})$ or Triton X-100 1\% $(\mathrm{w} / \mathrm{v})$ was as previously described (Hallas and Widdowson, 1982).

Pepsin extraction. Washed cells were extracted with pepsin as described by Beachey, Campbell and Ofek (1974).

Detection of OF. OF-activity in column fractions was measured by the tube method and titres in extracts and culture supernates were determined by the slide method (Maxted, Widdowson and Fraser, 1973; Hallas and Widdowson, 1982).

Protein detection. The method of Lowry et al. (1951) was used.

Detection of $M$ antigens. $M$ proteins of all strains used in our experiments were detected by double diffusion in a gel of Ion Agar (Oxoid Ltd, Basingstoke, Hants) $1 \%(\mathrm{w} / \mathrm{v}$ ) in distilled water, against the corresponding, type-specific absorbed anti-M serum prepared in rabbits.

Type $22 \mathrm{M}$ antigen was also detected by a complement-fixation test, modified to a microtitration technique (Bradstreet and Taylor, 1962). In this test the guinea-pig antiserum was used at a dilution of 200 to eliminate any cross-reactions. The presence of type $22 \mathrm{M}$ protein was also monitored by testing fractions for their ability to neutralise type-specific opsonic antibodies in human immune serum in the "direct" bactericidal test (Pinney and Widdowson, 1977).

Detection of $M$-associated proteins (MAP). MAP was detected in Lancefield extracts or 
fractions by a complement-fixation test with the appropriate antiserum (see above) containing either antibody to the MAP antigen of OF-negative serotypes (MAP I) or of OF-positive serotypes (MAP II) (Widdowson et al., 1976).

Sepharose $4 B$ chromatography and isoelectric focusing. The gel filtration and isoelectric focusing methods have been described by Hallas and Widdowson (1982).

Serial transfer experiments. A single colony of each strain was inoculated into $50 \mathrm{ml}$ of Todd-Hewitt Broth (Difco) supplemented with Neopeptone (Difco) $2 \%(\mathrm{w} / \mathrm{v})$ and incubated at 37 C. Samples of $0.02 \mathrm{ml}$ of the culture were transferred to fresh media at either $24-\mathrm{h}$ or $48-\mathrm{h}$ intervals. A total of six transfers were made for each serotype. Strain R68/3116 was plated after each transfer and approximately 1000 colonies were screened for OF activity in pour plates of Todd-Hewitt Broth supplemented with Neopeptone $2 \%(\mathrm{w} / \mathrm{v})$ and horse serum $30 \%(\mathrm{v} / \mathrm{v})$ and solidificd by the addition of Ion Agar $1 \%(\mathrm{w} / \mathrm{v})$. The plates were incubated at $37^{\circ} \mathrm{C}$ for $24 \mathrm{~h}$ and then at room temperature for $48 \mathrm{~h}$ after which time zones of opacity were readily seen (Widdowson et al., 1970). For all the other strains, a dilution of the culture from the sixth transfer was plated on to blood-agar plates to give approximately 200 colonies per plate. Twenty colonies were picked at random, replated, then subcultured into $50 \mathrm{ml}$ of Todd-Hewitt Broth. The supernates from OF-positive cultures were tested for OF activity by the slide method. The cell pellets from all the cultures were treated with $0.2 \mathrm{~N} \mathrm{HCl}$. The extracts were tested for $\mathrm{M}$ protein by double-diffusion in agar, and for MAP and OF antigens. The strains were aiso tested for their ability to survive in human blood (Widdowson et al., 1970).

Plasmid isolation. The lysate was initially prepared by the method of Clewell and Franke (1974). Protein was removed by extraction with either an equal volume of chloroform-isoamyl alcohol (24:1) or with 50mm Tris-saturated phenol (Meyers et al., 1976). A clear aqueous phase was obtained by centrifugation at $15000 \mathrm{~g}$ for $15 \mathrm{~min}$. Plasmid DNA was precipitated with cold ethanol at $-20^{\circ} \mathrm{C}$ overnight and recovered by centrifugation at $12000 \mathrm{~g}$ for $20 \mathrm{~min}$ at $-10^{\circ} \mathrm{C}$. The precipitate was resuspended in $0.1 \mathrm{ml}$ of TES buffer (Tris $30 \mathrm{~mm}$, disodium EDTA 5mM, $\mathrm{NaCl} 50 \mathrm{~mm}, p \mathrm{H} \mathrm{8.0)}$.

In some experiments, cells were lysed by reduced-phage-associated lysin (Gooder and Maxted, 1958) or by Streptomyces enzyme (McCarty, 1952). The effect of the addition of DL threonine $20 \mathrm{~mm}$ to the growth medium was also investigated because this modification has been shown to increase spheroplast formation (Chassy, 1976). In these experiments the lysozyme treatment was reduced to $15 \mathrm{~min}$ with $0.25 \mathrm{ml}$ of a solution containing $10 \mathrm{mg} / \mathrm{ml}$ (Klaenhammer, McKay and Baldwin, 1978).

Agarose-gel electrophoresis of plasmid DNA. The method of Meyers et al., (1976) was used. Plasmid preparations of known mol. wt $\left(5 \cdot 7 \times 10^{6}, 20 \cdot 2 \times 10^{6}\right.$ and $\left.26 \times 10^{6}\right)$ were obtained from Dr G. Willshaw, Division of Enteric Pathogens, Public Health Laboratory, Colindale. The control plasmid markers were included in all gel runs.

\section{RESULTS}

\section{Extraction of $O F$ and $M$ protein}

Because there is evidence to suggest that not all the activities of $M$ protein are associated with the same protein molecules (Fischetti et al., 1976), we considered it important to use more than one criterion to verify the presence or absence of $\mathrm{M}$ antigen in various extracts and fractions. The different extraction procedures produced varying amounts, both absolute and relative, of the two antigens (table I) and this caused difficulties in studying the relationship of OF with $M$ protein. OF, unlike $M$ protein, is sensitive to heat and low $p \mathrm{H}$. Therefore, extraction with $0.2 \mathrm{~N} \mathrm{HCl} \mathrm{at} 100^{\circ} \mathrm{C}$ for 10 min gave low OF titres but good yields of $\mathrm{M}$ protein, as detected by specific precipitation, complement fixation or neutralisation of opsonic antibodies. On the other hand, extraction with SDS produced excellent yields of OF but little detectable $M$ antigen. Detection of $M$ protein in these extracts is difficult because SDS interferes 
TABLE I

Extraction of $O F$ and $M$ protein from strain R68/3116 (T12 M22)

\begin{tabular}{|c|c|c|c|c|c|c|}
\hline \multirow[b]{2}{*}{$\begin{array}{c}\text { Extracting } \\
\text { agent }\end{array}$} & \multirow[b]{2}{*}{ Temperature } & \multicolumn{2}{|c|}{ Opacity factor } & \multicolumn{3}{|c|}{ M protein detected by } \\
\hline & & titre & $\begin{array}{c}\text { activity/mg } \\
\text { protein }\end{array}$ & $\begin{array}{l}\text { gel } \\
\text { precipitation }\end{array}$ & $\begin{array}{c}\text { type-specific } \\
\text { complement fixation }\end{array}$ & $\begin{array}{l}\text { neutralisation of } \\
\text { bactericidal test }\end{array}$ \\
\hline $\begin{array}{l}0 \cdot 2 \mathrm{~N} \mathrm{HCl} \\
0 \cdot 2 \mathrm{~N} \mathrm{HCl} \\
0 \cdot 2 \mathrm{~N} \mathrm{NaOH} \\
0 \cdot 2 \mathrm{~N} \mathrm{NaOH} \\
0 \cdot 05 \mathrm{~N} \mathrm{NaOH} \\
1 \% \mathrm{SDS} \\
1 \% \text { Triton } \\
\text { pepsin } 0.02 \mathrm{mg} / \mathrm{ml} \\
\text { Concentrated } \\
\text { culture } \\
\text { supernate }\end{array}$ & $\begin{array}{c}100^{\circ} \mathrm{C} \\
56^{\circ} \mathrm{C} \\
100^{\circ} \mathrm{C} \\
56^{\circ} \mathrm{C} \\
56^{\circ} \mathrm{C} \\
\text { RT } \\
\text { RT } \\
37^{\circ} \mathrm{C}\end{array}$ & $\begin{array}{r}64 \\
16384 \\
4 \\
64 \\
20480 \\
51200 \\
2560 \\
128 \\
8092\end{array}$ & $\begin{array}{c}17 \\
\ldots \\
\ldots \\
\ldots \\
18618 \\
21333 \\
\ldots \\
985 \\
225\end{array}$ & $\begin{array}{l}++ \\
\pm \\
+ \\
+ \\
\frac{ \pm}{v} \\
-\end{array}$ & $\begin{array}{c}640 \\
160-320 \\
<5 \\
80 \\
640 \\
\ldots \\
\ldots \\
\ldots \\
\ldots\end{array}$ & $\begin{array}{c}++ \\
\pm \\
\pm \\
+ \\
+ \\
+ \\
\cdots \\
\ldots \\
\pm\end{array}$ \\
\hline
\end{tabular}

$\ldots=$ not done; $\mathrm{V}=$ variable; $\mathrm{RT}=$ room temperature

non-specifically with the complement fixation and precipitation tests and it could not be removed sufficiently by dialysis to prevent this. Detergent did not interfere appreciably with the bactericidal test and low levels of $\mathrm{M}$ protein could be detected by this method. Extraction with $0.05 \mathrm{~N} \mathrm{NaOH}$ sometimes gave reasonable yields of both

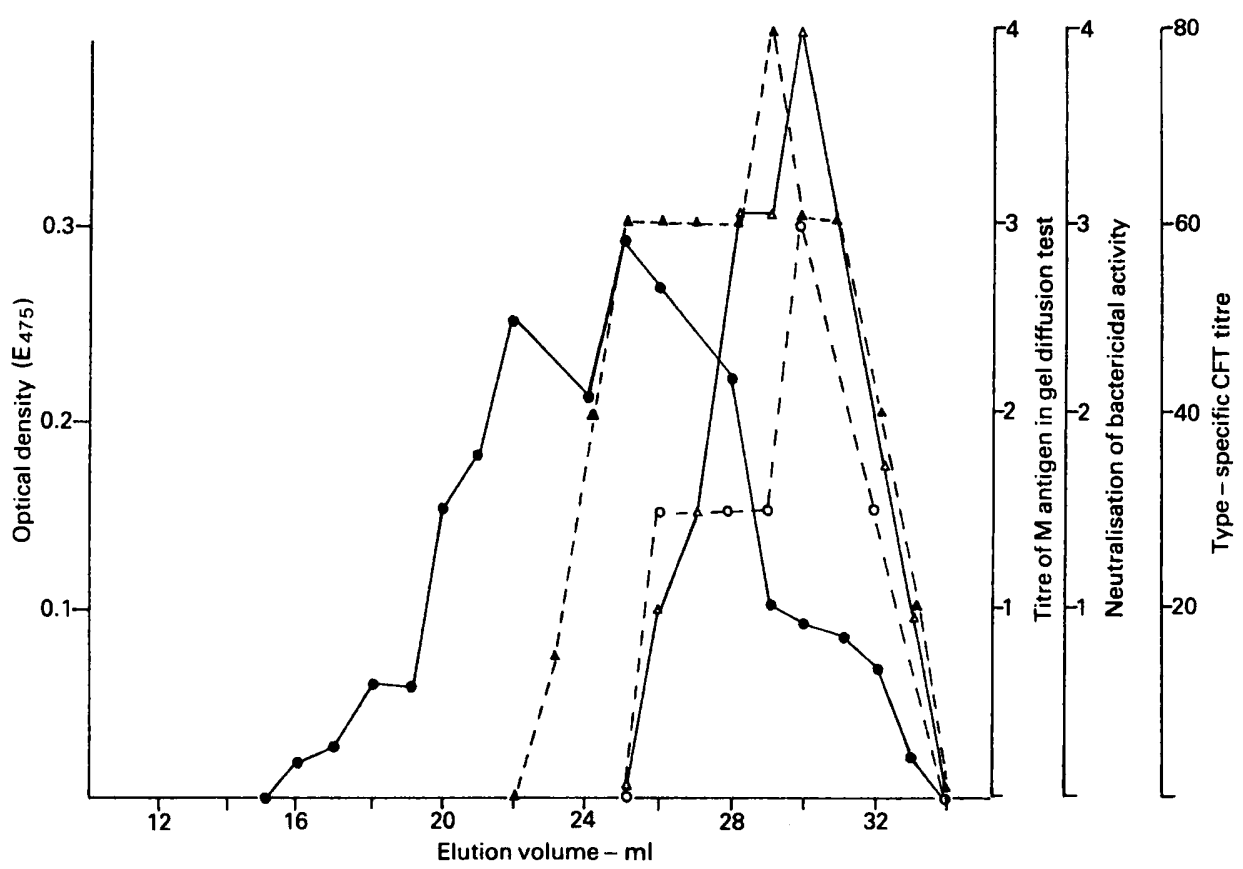

FrG. 1. Separation of acid-extracted OF and $M$ protein on Sepharose 4B. $\quad-\bullet=O F$ activity; $\Delta-\Delta=$ precipitin line formed with $M$-typing sera. $0-\ldots=$ type-specific complement fixation titre. $\Delta--\Delta=$ neutralisation of antibody in bactericidal test; $1+=$ neutralisation in neat fraction only, $2+=$ neutralisation at 2 -fold dilution of fraction, $3+=$ neutralisation at 5 -fold dilution, $4+=$ neutralisation at 10 -fold dilution. 
antigens but this was rather inconstant and although the yield of OF antigen was always high the $M$ content of the extract was often poor. Culture supernates of OF-positive strains contained easily detectable OF but apparently little $M$ protein (Pinney and Widdowson, 1977).

\section{Separation of acid-extracted $O F$ and $M$ antigen}

Sepharose $4 \mathrm{~B}$ chromatography of $0 \cdot 2 \mathrm{~N} \mathrm{HCl}$ extracts of strain $\mathrm{R} 68 / 3116$ showed that OF had a wide mol. wt distribution (fig. 1) and that fractions of OF with mol. wt $>6.6 \times 10^{5}$ were free of detectable $M$ protein as measured by three criteria - precipitation in gel, type-specific complement fixation and bactericidal neutralisation. Other OF-containing fractions (mol. wt $3.4 \times 10^{5}-5.0 \times 10^{5}$ ) were devoid of precipitating activity or complement-fixing activity with the absorbed homologous anti-M serum but retained some properties of the M-protein complex in that they appeared able to neutralise opsonic antibodies.

\section{Isoelectric focusing of $O F$ and $M$ antigen}

Isoelectric focusing of extracellular OF in a broad $p \mathrm{H}$ gradient (3.5-10) showed that a large proportion focused at $p \mathrm{H} 4 \cdot 0-4 \cdot 3$. Triton $\mathrm{X}-100$-extracted $\mathrm{OF}$, focused in the absence of detergent, formed three peaks of OF activity whereas alkali-extracted
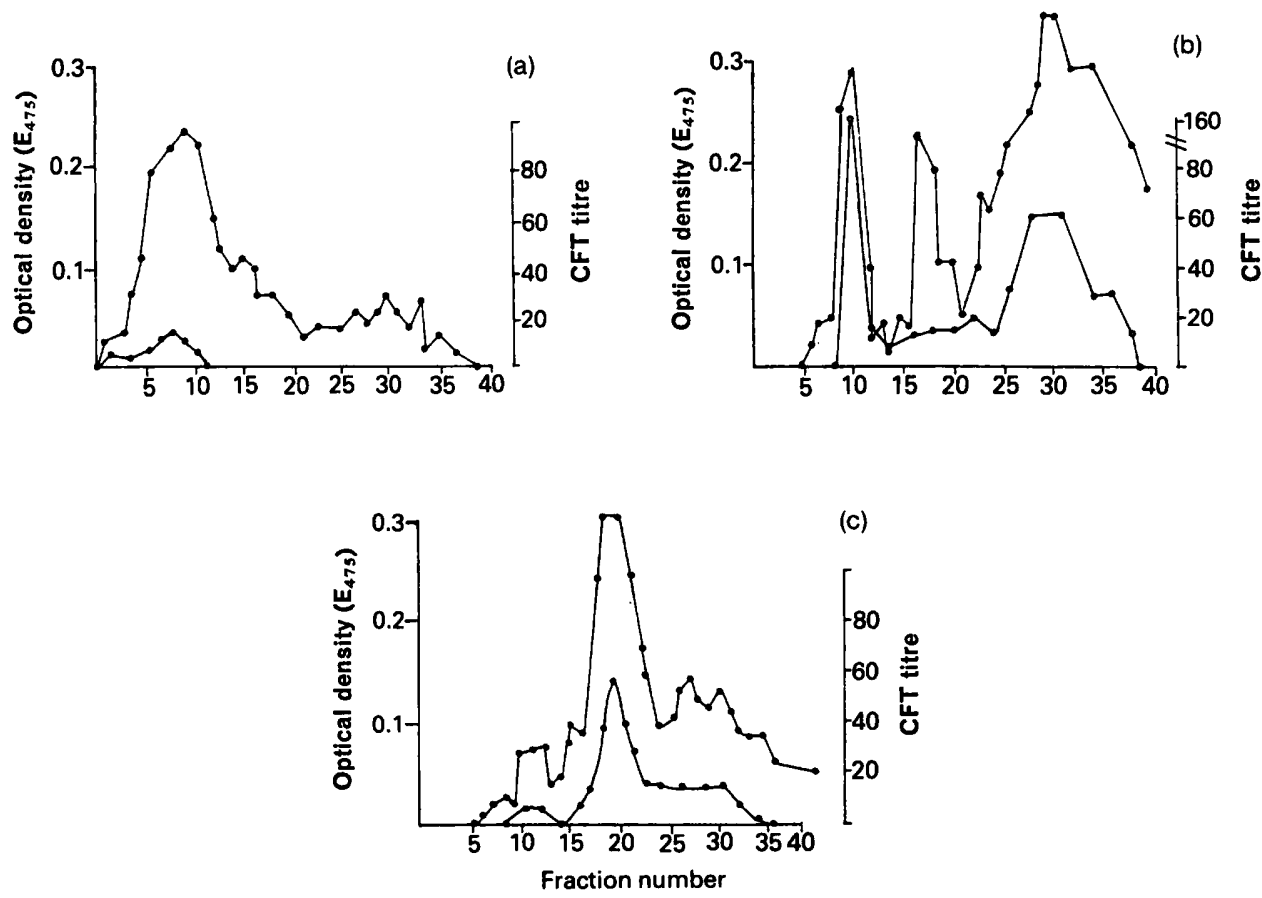

FIG. 2. Isoelectric-focusing profiles of $\mathrm{OF}$ and complement-fixing $\mathrm{M}$ antigen. $\bullet-\bullet=\mathrm{OF}$ activity; $\mathrm{O}-\mathrm{O}=$ complement-fixing $\mathrm{M}$ antigen. (a) extracellular OF; (b) Triton-extracted $\mathrm{OF}$; (c) alkaliextracted OF. 
OF formed a broad peak over $p \mathrm{H}$ range $5 \cdot 2-6 \cdot 2$. These focusing fractions were tested for the presence of $\mathrm{M}$ antigen by type-specific complement fixation and the results are shown in fig. 2. Complement-fixing activity was present in all three profiles in the fractions equilibrating at around $p \mathrm{H} 4.0$ and was very high in the Triton extract at this $p \mathrm{H}$. In addition, alkali-extracted $\mathrm{OF}$ had a complement-fixation peak at $p \mathrm{H} 5.6$ and

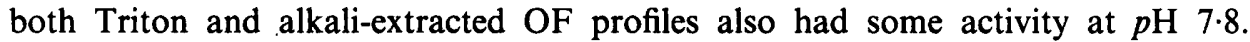
$M$ protein was undetectable by double-gel diffusion in these fractions even after concentration but isoelectric focusing of acid-extracted $\mathrm{M}$ protein, as detected by precipitation or by neutralisation of opsonic antibodies, showed that $M$ protein

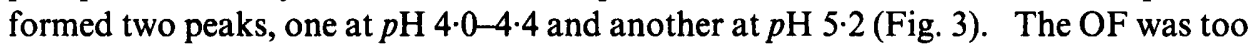
weak to detect after focusing.

These results show that the isoelectric focusing profiles of OF have a partial similarity with those of $M$ protein in that part of the OF activity focuses in the same position as $\mathrm{M}$ protein.

\section{Genetic relationship between $O F$ and $M$ antigen}

A detailed study was made of the rate of loss of OF and $\mathrm{M}$ antigens in strain $\mathrm{R} 68 / 3116$ after serial transfers in liquid medium at $24 \mathrm{~h}$ and $48 \mathrm{~h}$ starting from a single M-positive, OF-positive colony. At each transfer colonies were screened for OF activity in horse-serum pour plates. This strain produces large amounts of $O F$ and

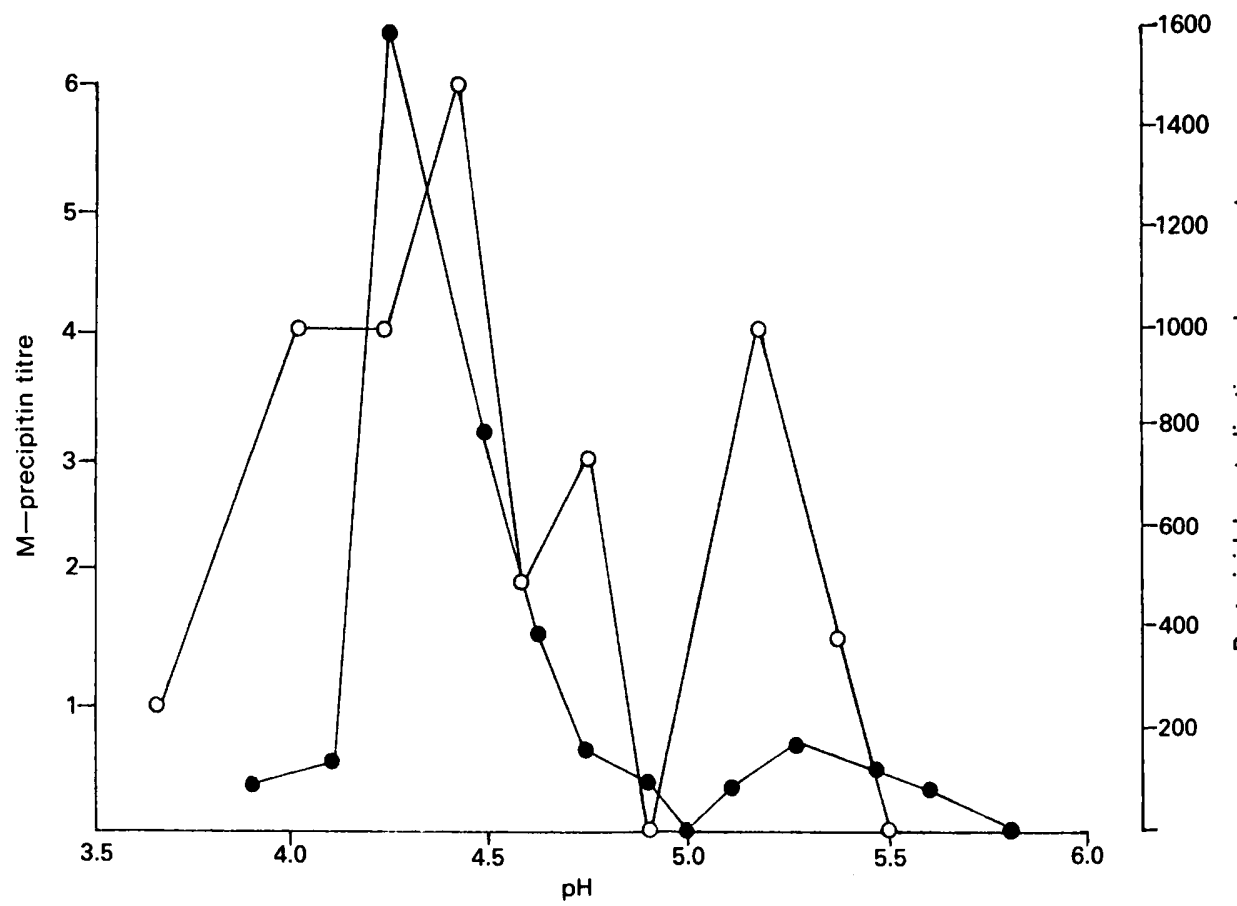

FIG. 3.-Isoelectric-focusing profile of acid-extracted M-type 22 protein. $0-0=$ precipitin; $\bullet-\bullet=$ bactericidal neutralisation. 


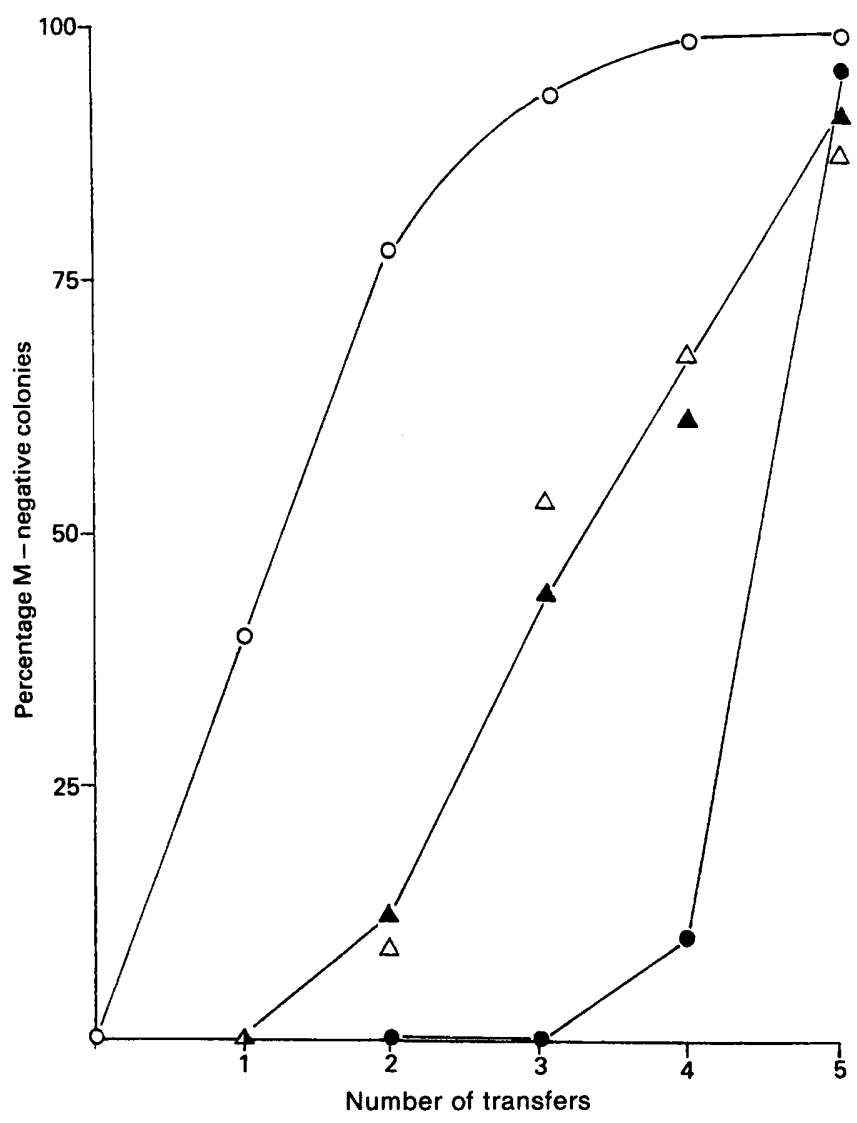

FIG. 4.- Rate of loss of $M$ and $O F$ antigens after serial transfer of strain R68/3116. $\Delta-\Delta=$ experiment 1 (48-h transfers); $\Delta-\Delta=$ experiment 2 (48-h transfers); $O-O=$ experiment 3 (48-h transfers); $\longrightarrow 24$ h-transfers.

OF-positive colonies formed a halo around each colony of $3 \mathrm{~mm}$ diameter. Colonies with reduced zones of $\leqslant 1.5 \mathrm{~mm}$ diameter were found to have little OF activity and these colonies were designated "OF-negative". In three separate serial transfer experiments with strain $\mathrm{R} 68 / 3116$ a total of 83 potentially OF-negative colonies were checked for extracellular OF activity which was always $\leqslant 8$; activity was $\geqslant 512$ in OF-positive colonies. All $83 \mathrm{OF}$-negative colonies were found to be M-negative also. Lancefield extracts from cultures grown from OF-negative colonies failed to give a precipitation line in gel with the homologous antiserum and had MAP titres of $<60$. Cultures from OF-negative colonies did not survive in human blood. Fig. 4 shows the percentage loss of OF after transfers at 48-h and 24-h intervals. In two out of three experiments, almost identical rates of loss of OF antigen were observed; some OF-negative colonies appeared after the second 48-h transfer. However, in the third experiment, some OF-negative colonies appeared after plating out the first 48-h culture and subsequently increased at a similar rate as in the previous two experiments, until after the fourth 48-h subculture, the culture was predominantly M-negative, 
TABLE II

Comparison of the rate of loss of $M$ antigen among different $M$ types of group- $A$ streptococci

\begin{tabular}{rrlcc}
\hline & & & \multicolumn{2}{c}{$\begin{array}{c}\text { Percentage of } \\
\text { colonies* } \\
\text { M-negative after six } \\
\text { serial transfers at } \\
\text { intervals of }\end{array}$} \\
\cline { 3 - 5 } M type & OF & Source & $48 \mathrm{~h}$ & $24 \mathrm{~h}$ \\
\hline 22 & + & Throat & 98 & 98 \\
60 & + & Skin & $\ldots$ & None \\
49 & \pm & Skin & $\ldots$ & 35 \\
5 & - & Throat & None & $\ldots$ \\
6 & - & Throat & None & $\ldots$ \\
12 & - & Throat & 100 & $\ldots$ \\
55 & - & Skin & 35 & 65 \\
57 & - & Skin & 65 & 40 \\
\hline
\end{tabular}

$\ldots=$ not done.

*All M-negative colonies from OF-positive strains were OF-negative.

OF-negative. Subculturing at 24-h intervals increased to three the number of transfers required to isolate OF-negative colonies.

\section{The rate of loss of $M$ antigen in $O F$-positive and $O F$-negative serotypes}

Six serial transfers were made at either 48-h or 24-h intervals with strains of seven serotypes. The presence or absence of $\mathrm{M}$ protein in 20 randomly selected colonies was determined by precipitation of Lancefield extracts in gel with the homologous antiserum and by the ability of the strain to survive in normal human blood. The percentage of M-negative colonies obtained after the final transfer is summarised in table II. Of the OF-positive serotypes studied, M-type 22 showed a very high $(98 \%)$ rate of loss of $M$ and OF compared with M-type $49(35 \%)$ and, in contrast, the M-type 60 strain studied was completely stable and no M-negative, OF-negative variants were isolated. Of the OF-negative serotypes studied, M-type 6 and M-type 5 were stable, but cultures of M-type 55 and M-type 57 both contained a high proportion of $M$-negative colonies after six $24-h$ or $48-h$ transfers and the loss of $M$ antigen was so rapid in $\mathrm{M}$-type 12 that no $\mathrm{M}$-positive colonies were recovered from the final subculture.

MAP is a non-type-specific antigen, closely associated with $\mathrm{M}$ antigen (Widdowson, Maxted and Pinney, 1971b). The MAP titre of the acid extracts was measured for the 20 isolates randomly selected from the final transfer of each serotype and a comparison of MAP titre and the ability to survive in human blood was made. Cultures with an MAP titre of $<60$ failed to survive in blood. Strains that possessed $M$ antigen and therefore survived in blood had MAP titres of $\geqslant 80$ (fig. 5).

The very rapid loss of $\mathrm{M}$ and $\mathrm{OF}$ in some serotypes would be explicable if, in the original colony, there were some M-negative, OF-negative cells which, coupled with a faster growth rate of the M-negative, OF-negative variant would ensure that the culture quickly became predominantly $\mathrm{M}$-negative, OF-negative. To test this 


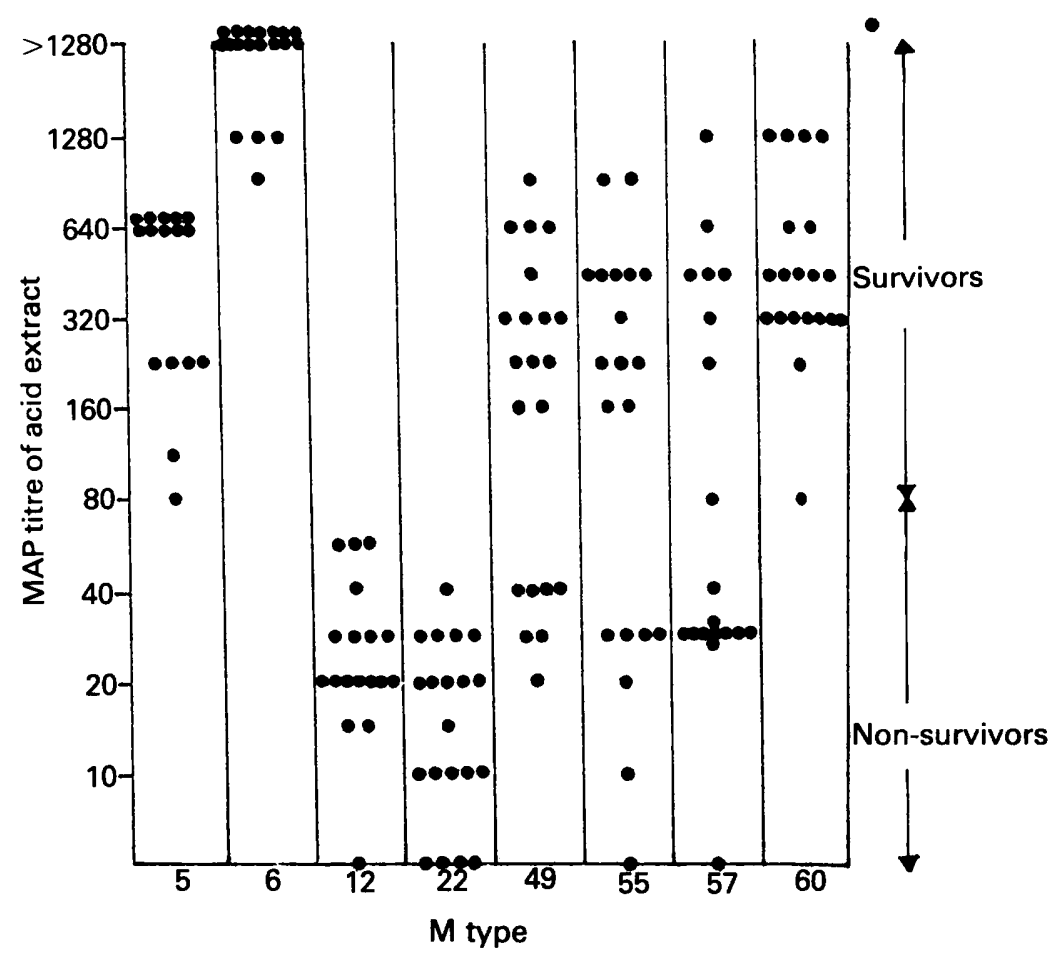

FIG. 5.-Relationship between the presence of $M$ antigen, as determined by survival in human blood, and MAP titre in different serotypes of group-A streptococci.

hypothesis, OF-negative colonies were sought after replating a single colony of strain $\mathrm{R} 68 / 3116$ that had been resuspended in $0.5 \mathrm{ml}$ of saline. Twenty randomly selected colonies, which represented $1.4 \%$ of the total number of colonies obtained, were screened and no M-negative, OF-negative colonies were obtained.

No M-negative colonies were obtained from a similar experiment with M-type 57. Furthermore the growth rates of $M$-positive and $M$-negative variants of an OF-negative strain were identical and in the OF-positive serotype, the M-negative variant had a slightly slower doubling time than the M-positive parent strain (fig. 6). The rapid loss of $M$ and $O F$ provides circumstantial evidence that the genes coding for $\mathrm{OF}$ and $\mathrm{M}$ antigens may be plasmid borne. This is supported by the fact that the $M$-negative, OF-negative state was very stable. After eight transfers at 48-h intervals of an M-negative, OF-negative variant of strain R68/3116, no M-positive, OF-positive colonies were found.

Examination of selected variants and parent strains for the presence of plasmids by agarose-gel electrophoresis

The simultaneous loss of $\mathrm{M}$ antigen and $\mathrm{OF}$ from some strains suggested that the genes coding for $M$ antigen and OF may be carried on the same plasmid. We attempted to demonstrate plasmids in M-positive and M-negative variants of M-type 


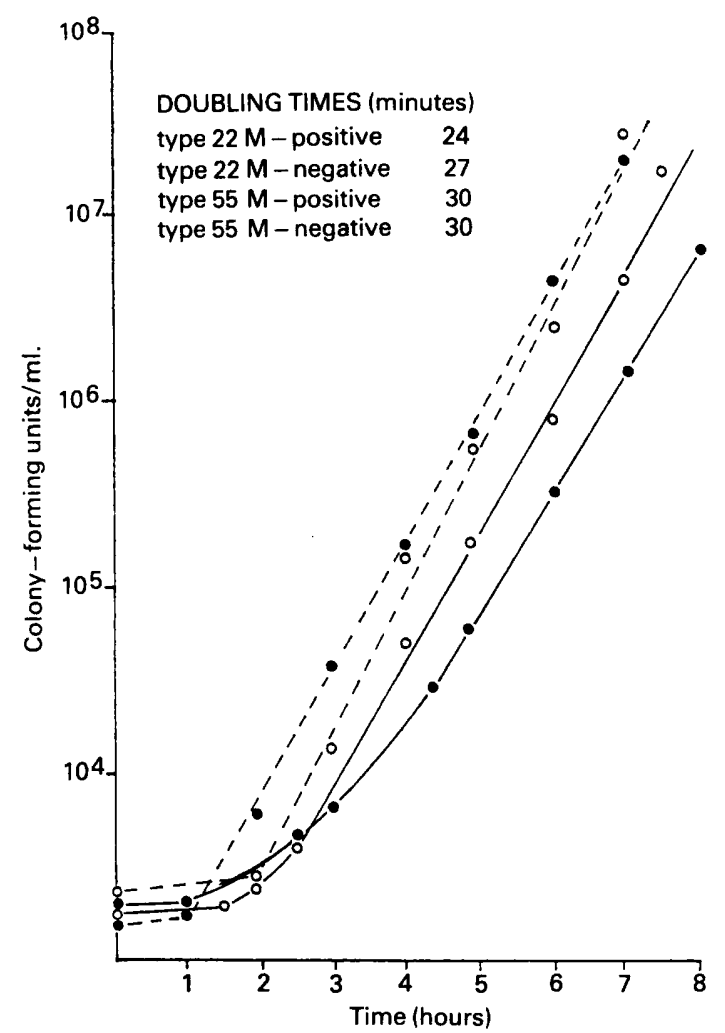

FIG. 6.-Comparison of the growth rates of M-positive parent strains with an M-negative variant of the same strain. $O--O=$ type $22 \mathrm{M}$-positive; $\bullet---O=$ type $22 \mathrm{M}$-negative; $\mathrm{O}-\mathrm{O}=$ type $55 \mathrm{M}$-positive; $\longrightarrow$ = type $55 \mathrm{M}$-negative.

22 and M-type 49 cultures by an agarose-gel electrophoresis method (Meyers et al., 1976). Plasmids were not detected in any of the strains by the method of cell lysis and DNA extraction described by Clewell and Franke (1974), and they were not detected in an erythromycin-resistant strain (AC-1) previously shown to harbour plasmids by Clewell and Franke (1974) who used a caesium-chloride density gradient technique. Alternative methods of cell lysis were then used because we considered that insufficient cellular lysis may have contributed to the lack of plasmids and that exogenous nuclease activity may have destroyed the plasmids during the long period of incubation with lysozyme. Partial lysis was obtained with Streptomyces enzyme and complete lysis was obtained with log-phase cultures and phage lysin but still no plasmids were detected. It was also considered possible that residual chromosomal material could obscure any high mol. wt plasmid present in the lysate. The agarose-gel concentration was increased from $0.7 \%$ to $1.2 \%$ in order to retard plasmid DNA and to increase the relative mobility of chromosomal DNA to give better separation of plasmid and chromosomal material. No plasmids were observed using the increased gel concentration. High mol. wt plasmids have been isolated from S. mutans, S. lactis and $S$. agalactiae grown in Todd-Hewitt Broth supplemented with $20 \mathrm{mM}$ DL threonine. Threonine has been shown to prevent cell-wall cross-linking in S. mutans (Chassy, 
1976) by inhibiting lysine incorporation. Cells grown in this medium were amenable to lysis with lysozyme $2 \mathrm{mg} / \mathrm{ml}$ for $15 \mathrm{~min}$ at $37^{\circ} \mathrm{C}$ and subsequent SDS treatment. The growth of group-A streptococci was reduced in medium supplemented with threonine. Initial experiments showed good lysis with short lysozyme incubations but this was inconsistent and lysis was partial in some experiments with log-phase cultures. No plasmids were detected in preparations lysed by this method. In all experimental runs, the control plasmid markers were always visible and in the correct position.

\section{DISCUSSION}

The nature of the relationship between $O F$ and $M$ protein has been investigated to some extent in previous studies and conflicting reports have been made on whether $O F$ and $\mathrm{M}$ protein are physicochemically linked or genetically related.

Widdowson et al. (1971a) suggested that OF and M protein may be part of the same molecule or complex because the two antigens were not separated in acid extracts when treated by the methods used for M-protein purification. However, more recent work has shown that $\mathrm{M}$-positive, OF-negative strains can be isolated from an M-positive, OF-positive parent culture by mutagenesis (Cleary, 1978) which suggests that OF and $\mathrm{M}$ are coded by two distinct genes. Moreover, temperate phage transduces the $\mathrm{M}$ protein marker alone or together with $\mathrm{OF}$, whereas virulent phages transduce the M-positive marker only (Totolian, 1979). Cleary et al. (1975) provided circumstantial evidence that $\mathrm{OF}$ and $\mathrm{M}$ antigens were plasmid-borne because $\mathrm{M}$-negative, $\mathrm{OF}$ negative variants segregated from the $M$-positive, OF-positive parent culture after serial transfer. A brief report (Totolian, 1979) describes the isolation of a peak of plasmid DNA in an M-positive strain by dye-buoyant density-gradient centrifugation which was absent in the $\mathrm{M}$-negative, OF-negative variant of the same strain, but more detailed information has not been published.

In this study we have shown that $O F$ and $M$ protein are apparently extracted to widely differing extents by different agents. This does not necessarily mean that the two activities are separable by varying the method of extraction, because boiling in acid may extract OF but subsequently destroy its activity, and SDS may interfere with some of the methods used to detect $\mathrm{M}$ protein. However, little, or no, $\mathrm{M}$ protein could be detected in extensively dialysed extracts with OF titres of $>50000$, so it seems likely that SDS preferentially extracts OF. $M$ antigen is a complex protein with a wide range of mol. wt and this depends partly on the serotype and the method of extraction. Thus Havlicek (1975) showed that high mol. wt M-type 12 protein, extracted by sonic disintegration, fixed complement with specific antiserum but did not yield precipitates with type-specific sera. Fischetti et al. (1976) studied M-type 6 protein, extracted by non-ionic detergent and found a mol. wt range of $6 \times 10^{3}-3.5 \times 10^{4}$. All the M-protein molecules precipitated with antiserum but anti-phagocytic activity was confined to the larger fractions of mol. wt $2.8 \times 10^{4}-3.5 \times 10^{4}$. Detailed physicochemical data is available only for the $M$ proteins of $O F$-negative types, e.g., 1, 3,6, 12 and 24 . There is some evidence to suggest that $M$ proteins of OF-positive types may differ in some properties, e.g., $p \mathrm{I}$, and separability of $\mathrm{M}$ from MAP (Widdowson, 1980), from the M protein of OF-negative types.

We have studied the physicochemical relationship between $M$ protein and $O F$ isolated from an M-type 22 strain using gel filtration and isoelectric focusing. 
Molecular seiving on Sepharose 4B of acid-extracted OF partially separated OF activity (mol. wt $7.5 \times 10^{4}-2 \times 10^{6}$ ) from $\mathrm{M}$ antigen (mol. wt $7.5 \times 10^{4}-3 \times 10^{5}$ ). The bactericidal neutralisation activity of the larger M-protein molecules was also partially separated from antibody-precipitating activity and was moreover associated with some of the OF-positive, non-precipitating fractions (mol. wt $3.5 \times 10^{5}-5 \times 10^{5}$ ). However, it is not possible to decide if the capacity of these fractions for neutralising the activity of type-specific antibody in bactericidal tests is directly related to their OF content, and some larger, OF-positive fractions (mol. wt $\geqslant 5 \times 10^{5}$ ) do not have neutralising activity.

Isoelectric focusing profiles of acid-extracted $\mathrm{M}$ protein of OF-negative types are generally consistent with a simple profile and $p \mathrm{I} c .5 \cdot 0$. The pattern is less clear for OF-positive serotypes (Widdowson, 1980). Acid-extracted M protein formed two peaks of activity at $p \mathrm{H} 4.2$ and 5.5 and similarly acid-extracted $\mathrm{M}$-type 2 protein has two peaks of activity at $p \mathrm{H} 4.7$ and 5.5 (unpublished observations). There may, therefore, be no simple relationship between $\mathrm{OF}$ and $\mathrm{M}$ protein but the data presented in this paper suggest that there may be some similarity between the two antigens because OF appeared to be associated with complement-fixing $\mathrm{M}$-protein activity in some crude extracts analysed by isoelectric focusing.

The rapid and simultaneous loss of $O F$ and $M$ antigen in some serotypes after serial subculture provided circumstantial evidence that these antigens may be coded by genes carried on a single plasmid. The presence of $\mathrm{M}$ antigen was monitored by two criteria, precipitation in gel with the specific anti-M serum and by the ability to resist phagocytosis in human blood. Agreement was found between the two methods, and the titre of acid-extracted MAP was also a good indicator of the presence or absence of $M$ antigen. A detailed study of the rate of loss of $M$ and OF was made for strain R68/3116. After the second 48 -h transfer, $10 \%$ of the colonies were $M$-negative and this increased to $45 \%$ and $65 \%$ after the third and fourth transfer respectively. By the fifth transfer $95 \%$ of the colonies were OF negative. The rate of loss of these antigens is comparable with that of a plasmid-mediated R factor in Salmonella (Watanabe and Ogata, 1970).

A study of strains of other $M$ types showed that the $M$ antigen of some representatives of OF-negative serotypes, e.g., 12, 55 and 57, were also lost rapidly on serial subculture. The type-12 strain was very unstable in our experiments. This strain has been shown to undergo phenotypic variation in natural populations in which antigenic shift from T12, M12 to T12, M62 was observed (Maxted and Valkenburg, 1969). However, this was not thought to have occurred in our experiments because none of the variants survived in human blood, which indicated a lack of $M$ antigen rather than a change in $M$ antigen. It is also interesting to note that the M12 antigen has been found in group $G$ strains (Maxted and Potter, 1967). It was noted that the "throat" strains associated with outbreaks of rheumatic fever, e.g., M-types 5 and 6, have very stable $M$ antigens. The single strains studied of serotypes associated with nephritis had unstable $M$ antigens with the exception of M-type 60. Clearly more strains of representative serotypes need to be studied.

M-positive, OF-positive colonies could not be isolated from serial subculture of $\mathrm{M}$-negative, OF-negative strains; this does not weaken the suggestion that the two antigens are plasmid determined, but the presence of plasmids could not be demonstrated directly by the agarose-gel method although several different methods of 
cell lysis were used. Also, an investigation of an erythromycin-resistant strain and its cured derivative showed that the genes coding for $M$ and OF were not carried on the same plasmid as genes coding for erythromycin resistance, because the parent strain and the cured derivative possessed the same $M$ and OF antigens, and also the curing process did not eliminate the hypothetical M-OF plasmid although there could have been more than one plasmid in these strains. No attempts were made to isolate plasmids by caesium-chloride density gradients and further work is required along these lines.

Although there are strong suggestions that the genes for $M$ antigen and $O F$ may be plasmid borne in some serotypes, there is no direct evidence; the hypothesis that the loss of these antigens is due to non-genetic variation must also be considered. The possibility that the colony initially selected was a mixture of $M$-negative and $M$-positive cells was excluded but the influence of the medium on the stability of $M$ and OF production was not investigated.

In the Streptococcus Reference Laboratory stock cultures of M-positive strains are stored in liquid media containing $5 \%$ horse blood, and subcultured approximately every 4 weeks. These cultures are usually stable, and the loss of $\mathrm{M}$ and OF activity is not a problem in most cases, although it is difficult to give quantitative data on this point. In earlier work on M-negative variants it was often difficult to isolate M-negative colonies by plating blood-broth cultures on blood agar (W. R. Maxted, personal communication). Thus it is possible that ability to produce $\mathrm{OF}$ and $\mathrm{M}$ protein in some serotypes is determined by an as yet undefined component that is lacking from Todd-Hewitt Broth with Neopeptone, and this aspect requires further investigation.

\section{REFERENCES}

Beachey, E. H., Campbell, G. L. AND OfeK, I. 1974. Peptic digestion of streptococcal M protein. II Extraction of $\mathrm{M}$ antigen from group $\mathrm{A}$ streptococci with pepsin. Infection and Immunity, 9, 891-896.

Bradstreet, C. M. P. AND TAYLoR, C. E. D. 1962. Technique of complement-fixation test applicable to the diagnosis of virus diseases. Monthly Bulletin of the Ministry of Health and the Public Health Laboratory Service, 21, 96-104.

ChASSY, B.M. 1976. A gentle method for the lysis of oral streptococci. Biochemical and Biophysical Research Communications, 68, 603-608.

ClearY, P. P. 1978. Genetic separation of serum opacity factor from M protein of group A streptococci. Infection and Immunity, 22, 171-175.

Cleary, P. P., Johnson, Z. and Wannamaker, L. W. 1975. Genetic instability of M protein and serum opacity factor of group A streptococci: evidence suggesting extrachromosomal control. Infection and Immunity, 12, 109-118.

Clewell, D. G. AND Franke, A. E. 1974. Characterization of a plasmid determining resistance to erythromycin, lincomycin and vernamycin $\mathrm{B} \alpha$ in a strain of Streptococcus pyogenes. Antimicrobial Agents and Chemotherapy, 5, 534-537.

Fischetti, V. A., GotSChlich, E. C., Siviglia, G. AND ZABRiskie, J. B. 1976. Streptococcal M protein extracted by non-ionic detergent. 1. Properties of the antiphagocytic and type-specific molecules. Journal of Experimental Medicine, 144, 32-53.

GOODER, H. 1961. Association of serum opacity reaction with serological type in Streptococcus pyogenes. Journal of General Microbiology, 25, 347-352.

GOODER, H. AND MAXTED, W. R. 1958. Protoplasts of group A $\beta$-haemolytic streptococci. Nature, 182, 808-809.

HaLlas, G. AND WIDDOWsOn, J. P. 1982. The opacity factor of group-A streptococci. Journal of Medical Microbiology, 15, in press.

HAVLICEK, J. 1975. M protein of type 12 Streptococcus pyogenes. Isolation by electro-focusing 
and some molecular weight-dependent properties. Pathologia et Microbiologia, 42, 147-158.

Klaenhammer, T. R., McKay, L. L. And Baldwin, K. A. 1978. Improved lysis of group N streptococci for isolation and rapid characterization of pasmid deoxyribonucleic acid. Applied and Environmental Microbiology, 35, 592-600.

Lowry, O. H., Rosebrough, N. J., FarR, A. L. and Randall, R. J. 1951. Protein measurement with Folin Phenol reagent. Journal of Biological Chemistry, 193, 265-275.

MCCARTY, M. 1952. The lysis of group A hemolytic streptococci by extracellular enzymes of Streptomyces albus. II. Nature of the cellular substrate attacked by the lytic enzymes. Journal of Experimental Medicine, 96, 569-580.

MAXTED, W. R. AND POTTER, E. V. 1967. The presence of type 12 M-protein antigen in Group G streptococci. Journal of General Micriobology, 49, 119-125.

MaXTED, W. R. and Valkendurg, H. A. 1969. Variation in the M-antigen of group-A streptococci. Journal of Medical Microbiology, 2, 199-210.

Maxted, W. R., Widdowson, J. P., AND Fraser, C. A. M. 1973. Antibody to streptococcal opacity factor in human sera. Journal of Hygiene, Cambridge, 71, 35-42.

Maxted, W. R., Widdowson, J. P., Fraser, C. A. M., Ball, L. C. and Bassett, D. C. J. 1973. The use of the serum opacity reaction in the typing of group-A streptococci. Journal of Medical Microbiology, 6, 83-90.

Meyers, J. A., Sanchez, D., Elwell, L. P. and Falkow, S. 1976. Simple agarose gel electrophoretic method for the identification and characterization of plasmid deoxyribonucleic acid. Journal of Bacteriology, 127, 1529-1537.

PinNEY, A. M. AND WidDowson, J. P. 1977. Characteristics of the extracellular M proteins of group-A streptococci. Journal of Medical Microbiology, 10, 415-429.

ToP, F. H. AND WANNAMAKER, L. W. 1968. The serum opacity reaction of Streptococcus pyogenes: frequency of production of streptococcal lipoproteinase by strains of different serological types and the relationship to $\mathrm{M}$ : protein production. Journal of Hygiene, Cambridge, 66, 49-58.

Totolian, A. A. 1979. Transduction of M-protein and serum-opacity-factor production in group-A streptococci. In Pathogenic Streptococci, edited by M. T. Parker, Reedbooks Ltd, Chertsey, Surrey, pp. 38-39.

WatANABE, T. AND OGATA, Y. 1970. Genetic stability of various resistance factors in Escherichia coli and Salmonella typhimurium. Journal of Bacteriology, 102, 363-368.

WidDowson, J. P. 1980. The M-associated protein antigens of group A streptococci. In Streptococcal diseases and the immune response, edited by S. E. Read and J. B. Zabriskie, Academic Press, New York, pp. 125-147.

Widdowson, J. P., Maxted, W. R. AND GRant, D. L. 1970. The production of opacity in serum by group A streptococci and its relationship with the presence of $\mathrm{M}$ antigen. Journal of General Microbiology, 61, 343-353.

Widdowson, J.P., Maxted, W. R., Grant, D. L. And Pinney, A. M. 1971a. The relationship between M-antigen and opacity factor in group A streptococci. Journal of General Microbiology, 65, 69-80.

Widdowson, J. P., MAXTED, W. R. AND PINNEY, A. M. 1971b. An M-associated protein antigen (MAP) of group A streptococci. Journal of Hygiene, Cambridge, 69, 553-564.

Widdowson, J. P., MAXTed, W. R. AND PinNey, A. M. 1976. Immunological heterogeneity among the M-associated protein antigens of group-A streptococci. Journal of Medical Microbiology, 9, 73-88.

Williams, R. E. O. AND Maxted, W. R. 1955. The type classification of Streptococcus pyogenes. Atti del VI Congresso Internazionale di Microbiologia, Roma. 1, 46-49. 